\title{
EDITORIAL \\ RBCE: DIVERSIDADE EPISTEMOLÓGICA E REGIONAL
}

São conhecidas as desigualdades regionais na produção acadêmica do Brasil. Não é diferente no caso da Educação Física/Ciências do Esporte. Apesar da imensa maioria dos artigos submetidos à RBCE serem de pesquisadores de instituições localizadas nas regiões Sul e Sudeste do País - também no contexto da ciência e tecnologia há profundas desigualdades no Brasil -, temos procurado um maior equilíbrio regional na composição de nossas publicações. Se os esforços da RBCE para consolidar-se como veículo a expressar e catalisar a diversidade teórica e metodológica que caracteriza a área têm alcançado êxito, como demonstram as edições publicadas desde setembro de 2008, segue o desafio, não apenas da revista, mas da Educação Física/Ciências do Esporte, de que a pluralidade também aconteça do ponto de vista geográfico. Isso precisa ser compatibilizado com os processos de internacionalização da pesquisa, em geral, e da RBCE, em particular, ao mesmo tempo em que deve encontrar outros movimentos, como o fortalecimento dos grupos de pesquisa e as parcerias entre pesquisadores de diferentes regiões do país. Esperamos que, paulatinamente, sejamos capazes de superar esses desafios.

Composto por artigos com temáticas variadas e com abordagens metodológicas diversas, o número atual da RBCE apresenta trabalhos oriundos de nove estados brasileiros, bem como uma contribuição da vizinha Argentina. Nele, o tema da formação de professores é analisado a partir de distintas perspectivas: na relação entre a Educação Física e a educação ambiental, na ressignificação do conceito de professor pesquisador reflexivo e a partir da presença do conteúdo esporte na formação inicial em Educação Física. $\bigcirc$ esporte continua em foco em vários dos trabalhos: na análise do comportamento da força do kitesurf em relação ao seu posicionamento e à distância percorrida pela barra de controle; na investigação antropométrica e somatotípica de atletas brasileiros de voleibol; na avaliação do desempenho e da contribuição da informação visual no controle postural de crianças praticantes e não praticantes de ginástica artística; nas possibilidades de promover a inclusão social por meio da sua prática em projetos sociais.

A pluralidade de temáticas e enfoques também se manifesta nos demais artigos originais: na avaliação do Programa Esporte e Lazer da Cidade (PELC) a partir de sua eficiência, eficácia e efetividade social; no estudo sobre o contexto sócio-político que favoreceu a fundação da Escola de Educação Física e Desportos do Paraná; na 
análise dos discursos e imagens utilizadas na construção do herói esportivo; na discussão sobre o currículo em Educação Física; na reflexão, a partir de Foucault, sobre a relação entre sujeito, corpo e educação; no exame da associação da insatisfação corporal e indicadores antropométricos em adolescentes; na verificação do efeito da ginástica laboral sobre dor nas costas e sobre hábitos posturais de trabalhadores que ficam longos períodos na posição sentada; na identificação de fatores motivacionais associados à prática de exercício físico em estudantes universitários; na apreciação das características termorregulatórias, dos recursos de prevenção e de diagnóstico do déficit hidroeletrolítico e danos causados pela prática do exercício no calor em crianças.

Um artigo de revisão, que discute a influência do exercício físico nas concentrações sanguíneas de adiponectina e sua associação com a sensibilidade insulínica, e uma resenha do livro organizado por Marco Antonio Coelho Bortoleto, Introdução à pedagogia das atividades circenses, publicado em 2008 pela Fontoura, completam a publicação.

Boa leitura!

Florianópolis, Vitória, setembro de $201 \mathrm{I}$.

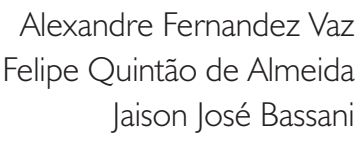

